\title{
Tax Farming As Panacea for Increased Revenue Generation in Nigeria
}

\section{Joseph, Fineboy Ikechi ${ }^{1}$, Akujor, Jane Chinyere ${ }^{2}$, Nwankwo, Kelechi Odii ${ }^{3}$}

${ }^{1}$ Department of Accounting, Faculty of Social and Management Sciences, Clifford University, Owerrinta, Ihie, Abia State.

${ }^{2}$ Department of Financial Management Technology, School of Management Technology' Federal University of Technology, Owerri, Imo State.

${ }^{3}$ Department of Accounting, Faculty of Social and Management Sciences, Clifford University, Owerrinta, Ihie, Abia State.

\begin{tabular}{ll}
\hline ARTICLE INFO & ABSTRACT \\
\hline Publication Online: & This study examines tax farming as panacea for increased revenue generation in Nigeria. Ineffective
\end{tabular}

19 February 2022 tax administration appears to be an unending setback in Nigeria as a result of myriad of challenges resulting in poor tax revenue generation. The study reviewed many previous studies on tax farming. The reviews revealed that tax farming leads to excessive exploitation of taxpayers in their bid to overzealously recover the advance payment to the government and running expense and then make profit. It was uncovered that the unpredictability and volatility of tenure of tax farmers results in lack of investment in the system because tax-farmers investments were not secured as their contract could be terminated by the state at any time thereby discouraging investment in the long-run. However, the advantages far outweigh the demerits. The study revealed that tax farming is in line with privatization, the current economic drive where the management of hitherto public enterprises has been transferred to competent private individuals to ensure efficiency and effectiveness of such organizations. Again, it ensured a highly coherent and efficient system of resource allocation. The system similarly provided guidance for resource allocation not only to the tax-farmers but also to the state. The tax-farming system was a very efficient revenue collection tactic for the state. It played a substantial role behind the decision of the state to invest directly in the various industries where it generated enormous tax revenue. The tax-farming system contributed significantly to the increase in capital in the private sector both by the massive profits it helped create and by compelling the entrepreneurs to form partnerships. Based on the findings via review of relevant literatures, the study recommends that tax farming should be introduced by the government and given legal backing in Nigeria as a veritable strategy for taxes and levies collection. Government should concentrate on tax administration which involves interpretation of the law and issuing guidelines, assessment, and auditing to ensure fairness and the rule of law which will entrench significant degree of monitoring of the government's agents while tax collection should be contracted out to tax farmers in the collection of determined tax arrears in order to stop over-collection. They should be engaged verification of value of goods declared by importers at customs to ensure that it corresponds to international price data. This would guarantee efficient revenue collection and accountability since the amount to be collected is already determined. The bidding and auctioning off process of tax farming to determine the right of private sector collectors to collect certain taxes and levies should be competitive and transparent to ensure that

Corresponding Author:

Joseph, Fineboy Ikechi maximum revenue is derived from the system and to avoid corrupt leaders ceding the right to collect taxes and levies to their cronies, a practice which negates the primary objectives of tax farming. The bidding process should be done at arm's length.

KEYWORDS: Tax Farming, Tax Administration, Tax Farmers, Collection Mechanism

\subsection{INTRODUCTION}

Unproductive and ineffective tax administration appears to be an unending setback in many developing countries. Myriad of challenges confront effective tax administration and practice in Nigeria, resulting in poor tax revenue generation.
Unwillingness of many taxable Nigerians to file in their tax returns or remit taxes for the fear that money raised may be siphoned off instead of being spent on health, education, critical infrastructure and other public services is one of such challenges. In other words, corruption is a bane to tax revenue 
generation in Nigeria. Studies have revealed more impediments to tax revenue generation in Nigeria. As opined by Simser (2008), when people deliberately refuse to abide by tax responsibility, it is called tax evasion. Tax evasion is seen to be as old as taxation itself because even from antiquity, people have been seen to be reluctant to comply with payment of taxes. Tax noncompliance is a serious challenge facing tax administration thus resulting in poor performance in terms of revenue generation in Nigeria. Huge amount of revenue leakages is enormous and this persists, it has devastating effect on the economy (Devos, 2008). One more inhibiting factor to tax revenue generation in Nigeria is lack of experienced personnel. The enforcement machinery of the country appears weak that taxpayers manipulate it with ease (Tijani and Ogundeji, 2013). The tax officials charged with the responsibility of tax policies implementation and administration seem to be ill-equipped because often times, they lack the basic skills needed to discharge their duties effectively and efficiently with its attendant low tax revenue generation and revenue leakages.

The recurrent and capital expenditure of the government has been on the rapid increase and the charge on debts servicing has grown over the years, but revenue increase or growth has not been proportionate to all these. Consequently, revenues generation has missed its targets by over $45 \%$ since 2015 irrespective of the fact that the Federal Inland Revenue Services (FIRS) is being commended for doubling the number of taxpayers since 2015 resulting to increased tax revenue generation.

An enormous change confronting Nigeria is the fall in the price of crude oil in the international market because the Nigerian economy depends largely on oil revenue to thrive. The average price of crude oil fell from around $\$ 113$ a barrel in 2012 to just over $\$ 54$ in 2017. The fluctuation in the price of crude oil has continued unabated because oil price is susceptible to vagaries of international market forces and international politics. Consequent upon the outbreak of coronavirus (COVID-19) pandemic, the price per barrel of crude oil fell below US\$20. This unexpected circumstance has forced the country into borrowing huge sum of money from foreign financial institutions at high interest rates. Unarguably, Nigeria is Africa' largest crude oil. Between 2012 and 2014, the oil sector provided 57\% of total government revenue. This fell to $41 \%$ between 2016 and 2018. The crash in crude oil price reached its crescendo below US\$20 following the COVID-19 pandemic.

For any nation to experience economic growth and development in the $21^{\text {st }}$ century, there should be a paradigm shift from crude oil revenue because of its unreliable and unpredictable nature. Tax revenue, having been proven to have reliability and predictability features is advocated for developing nations such as Nigeria. To this end, appropriate strategic mechanism suitable to our environment that would enhance tax revenue collection has to be put in place.
Organization for Economic Co-operation and Development (OECD) (2016), estimates that Nigeria has one of the world's least ratios of tax to GDP - a situation that calls for urgent fiscal and economic policy action. GDP refers to the total amount of tax revenues collected as a proportion of GDP - the totality of the value of the country's goods and services produced per annum. In 2016, total tax revenue to GDP stood at $6 \%$ (OECD, 2016). The tax-to-GDP ratio in South Africa was $29 \%$, Ghana stood at $18 \%$, Egypt $15 \%$ and Kenya $18 \%$ (OECD, 2016). It was estimated that the tax-to GDP average for OECD members - which includes all the advanced economies was $34 \%$. The World Bank adopts a slightly different measurement of tax which excludes majority of social security payments. This model applied by the World Bank placed Nigeria's tax-to-GDP ratio lower at just $3.4 \%$ in 2016. It was observed that in 2017, the ratio did advance to $4.8 \%$. The World Bank (2018) stipulates that $15 \%$ of tax-to-GDP is the level which is necessary to achieve economic growth and poverty reduction. It should be stressed that Nigeria should strive urgently to be practical oriented in the much needed tax reforms and administration and a such pragmatic approach should embrace tax farming because of its capacity to boost tax collection considering the peculiar nature of the Nigerian environment, the demerits notwithstanding.

In the light of the above, the adoption of tax farming as a policy option is being $\mathrm{x}$-rayed thus this study intends to critically examine the pros and cons of tax farming as a fiscal policy option with a view to ascertaining whether it is the appropriate tax collection strategy to enhance tax revenue collection in Nigeria.

\subsection{OBJECTIVES OF THE STUDY}

The objective of this study is to find out whether tax farming could be adopted as a reliable tax collection mechanism to enhance tax revenue generation.

In specific terms, the study is aimed at:

1. Ascertain whether tax-farming would be adopted as a veritable tool to boost tax revenue generation in Nigeria.

2. To determine whether tax-farming can be used as a tax collection mechanism to entrench transparency and accountability in the use of tax revenue by the government.

\subsection{RESEARCH METHODOLOGY}

This study intends to utilize secondary analyses. Secondary connotes literally a second hand analysis of data or information that was either gathered by other researchers, institutions and Non-Governmental organizations and so on or a critical re-interpretation of the available texts chosen from extant documents. Sources of secondary data are transcripts from focus groups, published texts, literature reviews and observation records. Documentations done and kept by individuals such as dairies and journals and accessed by other people are also viewed as secondary sources. This 
methodology is adopted so as to test the objectives upon which this study is predicted on. Similarly, making frantic efforts to ascertain the positive and negative consequences of tax farming could be done successfully upon the review of extant literatures relevant to the subject matter in question. Thus this methodology is justifiable on the ground that there are hard and soft voluminous academic materials on the research problems which are easily accessed by researchers the world over. More so, the study of tax farming as a policy for tax administration can reliably be done when a thorough study of the effect of tax farming on ancient and present economies has been done.

\subsection{Review of Related Literature Definition of the Concept of Tax Farming}

Tax farming represent a system where the right to collect certain taxes owed the state is auctioned off to the highest bidder in the private sector. It is also described as a system of for collecting taxes and other state revenues from the population. Tax farming is a representation of a private sector solution to the tax collection challenges. Under this system, the state transfers the right of collection to private individuals called tax farmers in exchange for a certain fee. The farmers accumulated great wealth since the taxes and charges they collected exceed by two or three times the amount deposited in the treasury. Tax farming is a feature of pre-capitalist system in which a natural economy is prime, credit is not developed, the state is in financial difficulties and communications are poor. Three varieties of tax farming were in existence and such include (a) general which covers a country or the whole tax system (b) regional comprising a single city or region and (c) special which centres on individual taxes, like customs duties or revenues from the liquor monopoly (The Great Soviet Encyclopaedia, 3rd Edition, 2010).

\section{History and Development of Tax Farming}

Tax farming became well-known in Iran in the sixth century B.C., and in Greece and Rome in the fourth century B.C. During the Middle Ages, it was widespread in France from the $13^{\text {th }}$ century and during the same period, it was practiced widely in Holland, Spain and England. Tax farming became one of the most important sources for ancient amassing of capital. While capitalism advanced, tax farming was preserved in a distinctive manner in $20^{\text {th }}$ century Italy, where private and saving banks did the collection of certain taxes. In the late 19th and early $20^{\text {th }}$ centuries, forms of tax farming were used for collecting arrears in the USA. Tax farming was extensively applied in the Ottoman Empire beginning the late $16^{\text {th }}$ and $17^{\text {th }}$ century; it was abolished in 1925 . It was also broadly practiced in Iran from approximately the tenth century to the 1930's and in India from $13^{\text {th }}$ or $14^{\text {th }}$ century to the $19^{\text {th }}$ century. Tax farming (otkup) was introduced in the late $15^{\text {th }}$ or early $16^{\text {th }}$ century in Russia. It was used especially for customs duties, salt and liquor revenues. Tax farming to collect liquor revenues was introduced in the $16^{\text {th }}$ century and assumed the greatest importance during the $18^{\text {th }}$ and $19^{\text {th }}$ centuries. Treasury revenues from the liquor tax constituted more than $40 \%$ of income from all taxes in the state budget. In 1863 tax farming to collect liquor revenues was abolished and replaced by excise tax (The Great Soviet Encyclopaedia, 3rd Edition, 2010).

\section{Ancient Origin of Tax Farming in Islam: An Institutional Background \\ Medieval Egypt - Daman and Qabala}

This institution engaged in tax-farming and was saddled with the responsibility of tax collection rather than resource allocation. Cizakca (1989) noted that the earliest evidence on the existence of Daman dates from 187 A.H. when Mahfuz b. Sulaiman auctioned off (Daman) tax collection for the whole of Egypt with the caliph (Morimoto, 1981: 228-229). Step by step, however, the system spread to smaller and smaller regions and more and more Damins engaged. As time went on, the Daman system metamorphosed into the Qabala which penetrated the entire country and was reduced to the village level. When the terms began Daman and Qabala were used interchangeably in Fatimid era, the lost their distinction.

On the basis of al-Maqrizi, Morimoto describes the functioning of the system as follows:

'When tax contracts for all the lands were to be made, the financial director of Egypt took up his seat in the Mosque of 'Amr b. al-'As in al-Fustat and people from villages and towns assembled there. A man indicated the various regions by shouting out the agreed quotas (sofoqot) for the contracts in turn, while the fiscal scribes in front of the financial director wrote down the quotas for kuras for which the auction had already been finished and the agreed quotas for those people among the crowd who had made a successful bid of their contracts for the taxes. The tax contractors (mutaqabbils) used to contract for the taxes of a specific region (balad) for a term of four years on account of draught, flood and other causes' (Morimoto, 1981: 232).

\section{Main Characteristics of this System}

Cizakca (1989) listed the features of the system as follows. First, the tax collection from the entire Egyptian countryside appears to have been organized in this system. Second, the decision as to who should collect the taxes from each tax zone was taken as a result of a competitive auction. Third, the term of contract of each mutaqabbil (tax-farmer) was valid for four years. In short, we have here a system which solves the problem of revenue collection from the land. At this point we may wonder just what induced the mutaqabbil to commit himself to the government and assume the responsibility of tax collection.

In theory, between the 8th and 10th centuries A.D. there was no obvious inducement for the tax contractors. They forwarded $50 \%$ of the auctioned amount to the treasury and kept back the remaining $50 \%$ with which they were supposed to fund irrigation work and other infrastructure investments (Morimoto: 244). However, in practice the 
mutaqabbils simply made use a part of this second half. This was their profit, that is, the ration for which they contested for in the auctions process.

Cizakca (1989) opined that during the Tulunid era (868-905 A.D.), the tax-farming system was well established in Egypt. The study argued further that the well-known Tulunid prosperity was mainly due to this system. The awesome importance of the tax-farming system for the financial arrangement of Tulunid Egypt is clearly confirmed by the following incident. Between 292 A.H and 905 A.D. the Abbasid armies conquered the Tulunids and after leaving a strong battalion and appointing a governor and a financial director returned to Mesopotamia. In the same year a former Tulunid general, Mohammed al-Haliji, rebelled and proclaimed the reinstatement of the Tulunids. The Abbasid governor and the financial director were forcefully compelled to withdrawal to Alexandria. Cizakca (1989) states that Morimoto notifies us that among the few essential things that they carried with them to Alexandria, the tax-farming records were the most important. Undeniably, the Abbasid rulers knew impeccably well that the tax-farming system constituted the backbone of the Tulunid financial power. Nevertheless this, probably taking full advantage of their familiar knowledge of the local affairs, the Tulunid rebels managed to detect the tax-farmers and compelled them to pay their contracted dues to them rather than the Abbasids. Simply put, a fight for the control of the tax-farmers had been fought between the contenders for power and the records of the tax-farming system obviously became the sine qua non of fiscal administration (Morimoto, 1981: 250-251).

Tax farming system witnessed a major during the late Fatimid era because there was the reduction of the sum forwarded to the Treasury from one half to one third of the total contracted sum. As a result, the amount usurped by the tax-farmers witnessed an increase, resulting to obvious increase in their profits as well as the competition in the auctions. Barkan (1953:270) opined that by the 10th Century A.D., about half of the revenue of Egypt was collected by the tax-farming system and he noted that this volume of revenue increased to about $80 \%$ in 1527.

In 'Ayyubid Egypt the tax-farming extended to all the sectors of the economy such as mining, fishing including the removal of ordure from urban dwelling. Besides, the military more and more became associated with the system which soon performed not only the task of revenue collection but also the upkeep of troops (iqta'). Participation of the military soon led to sub-tax-farming, whereby the officer (muqta) had the taxes of his allocation collected by locals appointed at private auctions (Rabie1972:137).

From the foregoing, the characteristics of the system of tax farming in Medieval Egypt can be summarized thus:

1. The system started initially with agricultural taxation due to a region and later spread to all the tax sources in the economy.

2. Through competitive bidding, a tax-farmer was delegated by the state the right to collect the taxes due to a tax source (mukataa). The highest bidder given the authority for the collection of the revenue. In this case, the tax-farmer took part of this revenue and transferred the remaining portion of the Treasury and the usurped portion represented his profit.

3. The tenure of tax-farmer was limited to four years.

4. The tax-farmer agreed with surety to pay to the state a certain sum, determined in the auction. It is the last feature which shows clearly that the tax-farmer was in fact an entrepreneur, a risk taker. Indeed, if the revenue he collected exceeded his total cost he enjoyed a profit. It should be pointed out that the total cost here includes the amount he paid to the Treasury plus his operational expenses. On the contrary, a situation where the tax revenue the tax-farmer collected dropped below the amount he had guaranteed to pay the state, the tax-farmer had suffered a loss in the auction. Where the tax-farmer is unable to offset the liability incurred with his personal assets, as a result of the loss, he would inevitably end up in prison and all his assets would be impounded.

\section{CONCLUSION}

Tax-farming institution in Egypt was known in Medieval Egypt as Daman-Qabala. Consequently, tax-farming dominated the life of the Muslims for more than one thousand years in a geographical dimension extending from the Atlantic to the Indian Ocean.

\section{Advantages and Disadvantages of Tax-Farming System- Ottoman European Provinces, Egypt, Anatolian provinces as Case Studies}

Advantages: It functioned as a highly coherent and efficient system of resource allocation. The system, also, provided guidance for resource allocation not only to the taxfarmers as fully explained above, but also to the state. Since the majority of the data presented in this article has been obtained from the records kept by the state, we can safely assert that the state was also well informed about the changing critical state of affairs in the economy as well as the comparative profitability of each sector.

This information, undoubtedly, played a substantial role behind the decision of the state to invest directly in the various industries (Cizakca, 1980: 145-147).

Additionally, the tax-farming system was a very efficient revenue collection strategy for the state. Essentially it was exactly for this motive that it was applied formerly. It is worthy of note that $23.16 \%$ of the total revenue of the Ottoman European provinces, $19.75 \%$ of the Anatolian provinces and lastly $80 \%$ of Egypt was collected through the Iltizam system in the 1527-28 financial year (Barkan, 1953).

In conclusion, the tax-farming system contributed significantly to the increase in capital in the private sector both by the massive profits it helped create and by compelling the entrepreneurs to form partnerships and sherkats (Cizakca, 1980:147). 


\section{Disadvantages:}

The most severe demerit was the excessive exploitation of the mukataa, more specifically, the peasantry. Indeed, most historians agree that the peasantry was callously exploited in this system, a clear violation of Islamic principles (Abu Yusuf, 1979:211). Yet it is clear that the unpredictability of tenure, the intervention of the military in the smooth functioning of the system, sub-tax farming as well as absentee landlordism were the main reasons behind this.

Another major disadvantage caused by the unpredictability and volatility of tenure was the lack of investment associated with the system. The tenure of the tax farmers was not secure as their contract could be terminated by the state at any time thereby discouraging investment in that direction in the long-run. These investments were not in the nature of continuous outlays designed to improve the mukataat. Consequently, a deterioration of the mukataat over time did occur.

\section{Argument Justifying the Adoption of Tax Farming}

Three plausibly different justifications of tax farming will be considered below:

\section{Administrative Cost Saving Rationale}

The largely common argument in favour of tax farming was that it allowed governments that are weak in terms of administration to minimize the cost of collecting tax revenues. Proponents of this view stress that savings accrues to government through the avoidance of the encumbrances of a large bureaucracy. Webber and Wildavsky (1986) put forward the argument that in sharp contrast to Egypt and India, the use of tax farmers in Mesopotamia (ca.1750 B.C) was a representation that the government needed only a comparatively modest administrative capability to bargain contracts and ensure the enforcement of the contract fees. This is the argument given as the rationale for the adoption of tax farming lately in variety of forms in Egypt and by many diverse governments during the late eighteenth century. Stella (1993) emphasized that when administrative scarce resources are economized, tax farming would present a potential Pareto improvement in comparison with government collection.

To determine the advantage of this argument, it is important to recognize that some organized entity had to undertake the expense of collection. The amount generated by a government at auction represented a private sector estimate of the net revenue that could be collected. Net revenue implies the total estimated revenues collected as tax revenue less estimated administrative cost to run the process of the collection of revenue from the taxable individual, group of individuals and corporate entities. It has become pertinent to prove that private tax collectors would be more effective and efficient in tax revenue collection than the government tax collectors. There is sufficient evidence that private tax collectors had to shoulder the expense of extensive collection networks. Take for instance, in primordial Rome, for example, the Senate bargained a single contract for all direct and indirect revenues from each far-away province and this was a large-scale undertakings. The consortium holding contracts in Bynthia in the first century B.C., for example, had tens of thousands of employees (Webber and Wildavsky (1986:116).

In the same way, in seventeenth-century France, the tax system was the leading employer offering job to at least 75,000 people for the purpose of tax collection alone. Collins (1988) opined that the peasant collectors themselves if counted among the employees of the system would add another 80,000 to 100,000 people to already gotten total. A breakdown of this figure showed that estimated 2 percent or 3 percent of adult male French population worked for the tax system each year. The implication is a replication of the bureaucracy witnessed in the government which results in little profit from tax collection in the private sector. For the state to set the rules and monitor play, it should be committed to the rule of law rather than discretion. The aim of modern developing country tax administrations and practice include the observation of the outcome of tax administration and the process of tax collection, safeguarding taxpayer rights and determining that the lawfully obliged revenue is collected appropriately and at the slightest social cost. Though tax farming makes easy monitoring the outcome, it complex the problem of monitoring he process. The greater the devolution the more difficult it is to monitor the process and attain accountability.

In terms of tax collection, this problem can be stern. As put forward by International Monetary Fund (1986:102), tax payments, by their meaning are compulsory, unrequited, non-repayable contributions levied by a government for policy purposes. Thus, tax collection does not involve two willing participants, and the main moral justification for allowing free operation of markets that transactions are voluntary is not present. Accordingly, one cannot rely on the market to produce a suitable outcome. Finally, problem concerns the contact to secret proprietary information that would apparently be needed to execute auditing and investigatory functions of tax collection. There could be conflicts of interest between private tax farmers and other firms because tax farmers may take undue advantage of tax assessment to have access confidential or proprietary information to acquire an undue advantage of the firms being assessed Stella (1993).

\section{Sovereign Borrowing Made Easy Rationale}

Tax farming served to assist sovereign borrowing from the farmers. Problems coming up from shallow or imperfect credit markets or market failure owing to moral hazard problems were mitigated to the extent that tax farms, representing the right to collect certain established taxes, served as collateral for risky loans by the farmer to sovereign governments. It is important to note that this proposition is more importantly different from the administrative cost saving rationale in that it does not require private collectors to be more efficient than public collectors. Indeed, the private 


\section{"Tax Farming As Panacea for Increased Revenue Generation in Nigeria"}

sector might be less efficient yet the requirement by private lenders that governments offer collateral for loans resulted in collection being placed in private hands (Stella, 1993). The fact that it readily served as collateral for government for borrowing made it widely acceptable then. By this arrangement, it became harder for the state to reject the tax farming agreement than a simple loan. This assumption has some validity, since neither the sovereign nor his surrogates would typically have the specialized ability to take over the collection apparatus on short notice. Thus, tax farming may have served as a form of pre-commitment on the part of the government (Stella, 1993). Broadly speaking, it is clear that improvements in tax compliance are an effective way to improve a nation's creditworthiness since it could serve as collateral to obtain foreign loans. It mean therefore that since taxpayers are always unwilling to pay taxes, its collection by outside from whom the loan has been collected needs the total legal enforcement of the government that receives the credit facility. Otherwise, there would be noncompliance on the part of the taxpayers especially in developing countries where the populace have developed apathy towards tax payment owing to high rate embezzlement of public fund realizable from tax revenue.

\section{Revenue Collection Maximized Rationale}

Stella (1990) opined that tax farming will result in overcollection notwithstanding a litany of complaints from the taxpayers. A situation where the state intends to maximize revenue instead of economic welfare, tax farming would effectively and efficiently serve this purpose. Over zealousness in tax collection practice can lead to abuse of powers by tax officials resulting in violence. Tax farming produces the maximum amount of net revenue because it offers the farmer profit-maximizing inducement to maximize net revenue collected to maximize profit.

This argument is basically dissimilar to the first two in that it shows tax farming as a socially inefficient institution leading to over expenditure on tax collection in the quest of the tax farmer to enforce collection strategies resulting in increased administrative expenses. In this instance, such a institution may be preserved either because it represents the best option among available technologies, that is, it is a second-best solution or because the government has an objective function that does not suitably value citizens' preferences (Stella, 1993).

The historical documentation is stuffed with evidence that farming resulted in overzealous collection. Higgs (1928:71) reported that France the practice of farming the indirect taxes to the highest bidder gave rise to revolting harshness in collection. The tax collectors became harsh in their attempt to ensure that tax payers remit their taxes as and when due notwithstanding their reasons. De Vries (1976) noted that the Dutch Republic's experience during the seventeenth and early eighteenth centuries was that tax farmers controlled the excise tax collections; each year the tax collection privileges on forty-three separate excises were contracted out to the highest bidders. The study stated that the system produced social discord that generated the most significant riots in the Republic's history (De Vries 1976: 202). Even Adam Smith in 1776 in Wealth of Nations criticized the behaviour of tax farmers (Smith (1937)). Bid rigging and a general lack of competition were among the features tax farms. The leases were awarded by Court favour and led to much ruse and corruption, always to the detriment of the public. The farmer made large profits and it was based on the accusation of this swindling that the farmers generally were executed during the Revolution (Higgs (1928:71)). This problem has important implications for developing countries where the shortage of skilled personnel and excessive corruption would not permit effective competition.

\section{Tax Farming as a Second-Best Solution}

Stella (1993) opine that tax farming obviously has defects, particularly the too much revenue effort; and the practical alternatives are far from perfect and may result in insufficient revenue collections. Though the best system is not the one that generates the most revenue, there are those who argue that revenue generation is the most important objective of the tax system (Tanzi, 1989).

This section x-rays tax farming as a second-best solution. In considering whether to embark on tax reform or not, it is important to make a diagnosis of the challenges of existing tax administration problems in order to come up with appropriate alternative solution. In some cases the government salary schedule has been compressed and reduced to the point where it is not possible to recruit or retain qualified personnel with the specialized talents required for tax administration. Raising wages may be politically or administratively difficult to reduce pressure from the rest of the civil service in their quest to be to be treated similarly. Another challenge in some countries is that it is very difficult to dismiss anyone from the civil service thus giving rise to difficulties in dealing with poor performers. Corruption is not left out as one of the major challenges. One technique to the salary problem is to compensate the tax administration based on its revenue performance.

Chand and Lorie (1992) noted that, economies in the process of being transformed from centrally planned to market oriented reduction in real salaries of tax administrators revenue-related bonuses may play an important role in motivating tax officers. Such incentive systems are similar to tax farming, although the important difference that government official will most likely be subject to a set of political, ethical, and administrative constraints that a private farmer would not essentially adopt.

In Argentina and Bolivia, for instance, the amount retained by the tax authority for its use is based on a percentage of the total tax collection. This, in turn, means that the percentage rate is pretty low and, as a result, the marginal incentive is low. On the other hand, the administration could be rewarded on the basis of a percentage of the collections 


\section{"Tax Farming As Panacea for Increased Revenue Generation in Nigeria"}

over a predetermined target. In this latter case a higher marginal compensation could be offered with the same overall cost. The current system has the effect of increasing the tax officials' basic remuneration and does not change incentives very much particularly since any one individual's contribution to overall collections is likely to be small. In order to fundamentally change incentives, a higher marginal reward would have to be offered. In the limit, receiving 100 percent of collections above a certain threshold would present the government tax official with the same incentives as a tax farmer. In other cases the tax administration may be engulf with corruption, and severe measures are necessary.

Before the consideration of tax farming, one must determine whether there is an indisputable political devotion to reform at some higher level. In the absence of such a commitment, tax farming may simply replace a centralized type of corruption for a decentralized one. Another issue worthy of consideration is that one may overestimate the net revenue gain to be derived from abolishing corruption. If the venal tax collector has simply accepted an average level of bribes that brings his or her wage to the alternative he or she could obtain elsewhere, then the wages the private sector farmer would have to pay his or her employees, presuming corruption were eliminated, would be that much higher. In such a case the tax farmer could not offer the government higher net revenue than is currently being obtained (Stella, 1993). On the other hand, in circumstances where the public collector cannot be fired and entry into the tax collection profession is restricted, the public employee could generate a level of bribes that would bring his or her compensation above the private sector equivalent and this would advocate a need for civil service reformation. In other circumstances public revenue collection is weak for reasons that would not be addressed by private collection. Vague or excessively complex laws, an ineffective legal enforcement apparatus, or a large underground economy are all situations wherein tax farming is not likely to get better the situation. Moreover, if the legal system cannot be relied upon to successfully monitor the behaviour of tax farmers, the adverse consequences of private sector collection could be severe up. In reality, tax administration involves many different identifiable stages beginning with the issuance of interpretations of tax law, regulations, and guidelines, to the collection of court-awarded tax arrears and penalties. In consideration of the wide range of activities that are the task of tax administration it is appropriate to consider areas that might be suitable for privatization. Based on the previous discussion, only activities that involve little vagueness, judgment, interpretation, and discretion would properly fit in to privatization. The collection of known tax arrears describes a case where the judicial system has already decided on any issues in disagreement and where what is required is simply collection. Data processing services and employer-mandated tax withholding are other cases where the private sector can be valuably involved. In relation to later, the employer does not play any role in the determination of the final tax liability of the taxpayer thus simply serves as an agent in the retention or withholding process. The nucleus activities of the tax administration which entails interpretation of the law and issuing guidelines, assessment, and auditing are areas where, if the government is dedicated to fairness and the rule of law, a considerable degree of monitoring of the government's agents is needed. Analogically speaking, it can be argued that the privatization of prisons results in efficiency gains, but a society committed to justice and equality before the law could not privatize the course of action by which an individual is sentenced to prison (Stella, 1993). Therefore, where tax administration cost is high, tax farming is the most suitable option to apply. Take for instance, in Argentina; it has been proposed that the collection of tax arrears be contracted out to private firms that would retain a share of collections.

In this case, since private collection efforts would be aimed only at those with identified tax arrears, there would be little scope for over-collection. Other countries have contracted private companies to administer part of the customs functions like the verification of the value of goods declared by importers at customs that corresponds to international price data. The verification task is privatized without ceding the actual right to collect taxes. This study argues that the collection of tax on the value of goods declared by importers at customs should also be the private companies hired in the verification exercise thus need for tax farming. Furthermore, if corruption is nipped in the bud and the bidding auction made competitive, tax farming would, no doubt, boost revenue generation in Nigeria.

\subsection{THEORETICAL FRAMEWORK}

The Socio-Political Theory: This theory of taxation posits that social and political objectives should be the key factors in selecting taxes. The theory believes that a tax system should not be planned in such a way that individuals are served, but should be used to treat the ills of society as a whole (Bhartia, 2009). It should be pointed out that such ills include absence of basic infrastructure, poor educational system, insecurity, unstable political system and poor judicial system resulting to human right abuse et cetera. Since economic and political objectives of a government are inseparable and needed for speedy growth and development of a country and tax revenue is needed for such advancements, this theory is therefore relevant to this study because it talks about growth and development within the economy.

\subsection{CONCLUSION AND RECOMMENDATIONS}

Tax collection and administration are not a monolithic activity. Tax administration involves many different identifiable stages beginning with the issuance of interpretations of tax law, regulations and guidelines, to the collection of court awarded tax arrears and penalties. This degree of simplification is evident as well and in many 
theoretical works on tax evasion, the tax collector is usually confined to setting an audit strategy and a penalty structure. In consideration of broad range of activities that are the duty of the tax administration it is fitting to consider which might be suitable for privatization and which would not and it is on this ground that this study makes some recommendations.

- Since the world economies are driving towards privatization which has been proven over the years to be more efficient and effective, adopting tax farming in tax collection would no doubt replicate the same efficiency and effectiveness characterized in privatized economy.

- The government should concentrate in tax administration which involves interpretation of the law and issuing guidelines, assessment, and auditing are areas where, if the government is committed to fairness and the rule of law, a significant degree of monitoring of the government's agents is required, while tax collection should be contracted out to tax farmers in the collection of tax arrears in order to stop over-collection and verification of value of goods declared by importers at customs to ensure that it corresponds to international price data as well as ceding the actual right to collect taxes. This would guarantee efficient revenue collection and accountability since the amount to be collected is already determined.

- Tax farmers should be involved in data processing services in conjunction with employer in the collection of withholding taxes are since it is (employer plays no role in the determination of the ultimate tax liability) determined in advance in percentage and the employer only serves as an agent of retention.

- Tax farmers should be involved in private collection efforts aimed at those with identified tax arrears as this would stop the chances of over-collection- a criticism levelled against tax farming.

- Since some of the approaches to ensure that the welfare of taxpayers is guaranteed are to protect them from exploitation or being 'over-taxed' as well as the provision of basic amenities and infrastructural facilities, government should concentrate on tax administration activities while the actual tax collection responsibility should be auctioned off to tax farmers to ensure efficiency and effectiveness in tax collection which would boost revenue generation for the provision of welfare packages.

- In order to avoid taxpayers' abuse only unambiguous activities (tax administration) could be privatized while the collection of already determined tax liabilities should be auctioned off tax farmers.

- Levies and other related duties should be farmed in a transparent manner and revenue so generate published in official government gazette on monthly, quarterly, half yearly and annually in order to inform the taxpayers the total revenue generated through their obligations to the government. This would help them to hold the government accountable should it fail to discharge its responsibility in terms of provision of infrastructural facilities, social amenities, security and economic regulations.

\section{REFERENCES}

1. Barkan, O. L. (1953). "H. 933-934 (M. 1527-1528) Mali Yilina Ait Butee Ornegi". Iktisat fakultesi Mecmuasi (Istanbul Umiversitesi) Vol.15, Nos. 1-4: 259-329.

2. Collins, J. B. (1988). Fiscal Limits of Absolutism (Berkeley: University of California Press, 1988).

3. Chand, S. K. and Henri, R. L. (1992). Fiscal Policy, in Fiscal Policies in Transitione, d. by Vito Tanzi (Washington: International Monetary Fund, 1992).

4. Cizakca, M. (1989). Tax-Farming and Resource Allocation in Past Islamic Societies JKAU: Islamic Econ., Vol. 1, pp. 59-80 (1409 A.H./1989 A.D.).

5. Devos, K. (2008). Tax evasion behaviour and demographic Factors: An Exploratory Study in Australia, Review Law Journal18 (1), 1-43

6. De Vries, J. (1976). The Economy of Europe in an Age of Crisis, 1600-1750 (Cambridge, England: Cambridge University Press, 1976).

7. Higgs, H. (1928). The French Revolution,' in The Cambridge Modern History, Vol. 8 (New York: Macmillan, 1928).

8. International Monetary Fund: A Manual on Government Finance Statistics (Washington: International Monetary Fund, 1986).

9. Morimoto, K. (1981). The Fiscal Administration of Egypt in the Early Islamic Period, Kyoto: Dohosha Publ. (Asian Historical Monographs, No. 1).

10. OECD (2013). What drives tax morale? Tax and development program, Center for Tax Policy and Administration.

11. Rabie, H. (1972). The Financial System of Egypt, 1169-1341. London: Oxford University Press, (London Oriental Series, Vol. 25).

12. Simser, J. (2008). Tax evasion and avoidance typologies. Journal of Money Laundering V Control, 11(2), 123 - 134.

13. Smith, A. (1937). The Wealth of Nations (New York: Modern Library, 1937).

14. Stella, P. (1992).Tax Farming - A Radical Solution for Developing Country Tax Problems? Article in Staff Papers - International Monetary Fund.

15. Tijani, O. M. and Ogundeji, M., (2013). Professional perspective of tax evasion: Some evidence from Nigeria. Universal Journal of Accounting and Finance, 1 (2), 35-41.

16. The Great Soviet Encyclopaedia, 3rd Edition, 2010).

17. Tanzi, V. (1989). Fiscal Policy and Economic Reconstruction in Latin America: IMF Working Paper 
"Tax Farming As Panacea for Increased Revenue Generation in Nigeria"

89/94 (Washington: International Monetary Fund, November 1989).

18. Webber, C. and Wildavsky, A. (1986). A History of Taxation and Expenditure in the Western World-New York: Simon and Schuster.

19. The World Bank (2018). The tax-to-GDP ratios of countries globally. 